\title{
Anthelmintic resistance of injectable macrocyclic lactones in cattle: A systematic review and meta-analysis
}

\author{
Resistência das lactonas macrocíclicas injetáveis em bovinos: uma revisão sistemática e meta-análise \\ Barbara Haline Buss Baiak ${ }^{1}$ (D); Cheila Roberta Lehnen ${ }^{1}$ (D); Raquel Abdallah da Rocha ${ }^{1 *}$ \\ ${ }^{1}$ Programa de Pós-graduação em Zootecnia, Departamento de Zootecnia, Universidade Estadual de Ponta Grossa - UEPG, \\ Ponta Grossa, PR, Brasil
}

Received July 26, 2018

Accepted November 26, 2018

\begin{abstract}
The purpose of this work was to identify, critically assess, and summarize available data from primary research about the anthelmintic resistance of injectable macrocyclic lactones in cattle. Meta-analysis was performed to estimate the pooled Odds Ratio and 95\% Confidence Intervals. Of the 1504 abstracts screened for eligibility, 80 were deemed relevant for full publication review. Thirteen publications were included in the qualitative synthesis and assessed for systematic bias. Only five studies were included in the quantitative analysis because they showed a low risk of producing biased results in all the parameters. The forest plot indicated four studies that discuss anthelmintic resistance $(\mathrm{P}<0.05)$, while only one study did not discuss anthelmintic resistance $(\mathrm{P}<0.05)$. The pooled estimate showed $0.59(95 \%$ Confidence intervals: $0.08,0.47)$ times higher odds for studies that report anthelmintic resistance than for studies reporting efficacious anthelmintic treatment, with significant and substantially low heterogeneity $\left(I^{2}=25 \%\right)$. Anthelmintic resistance to injectable macrocyclic lactones is a reality. There are need to improve methodological reporting in studies, which is a problem for investigations that involves systematic review and meta-analysis (SR-MA).
\end{abstract}

Keywords: Anthelmintic drugs, nematodes, ivermectin, moxidectin.

\section{Resumo}

O objetivo deste trabalho foi identificar, avaliar criticamente e resumir os dados disponíveis da literatura primária sobre resistência anti-helmíntica a lactonas macrocíclicas injetáveis em bovinos. Uma meta-análise foi realizada para estimar o "Odds Ratio" e Intervalos de Confiança (95\%). Dos 1504 resumos selecionados para elegibilidade, 80 foram considerados relevantes para a revisão completa da publicação. Treze publicaçôes foram incluídas na síntese qualitativa, as quais foram avaliadas quanto ao viés sistemático. Apenas cinco estudos foram incluídos na análise quantitativa porque apresentaram um baixo risco de produzir resultados tendenciosos em todos os parâmetros. O gráfico de floresta indicou quatro estudos que apresentaram resistência anti-helmíntica $(\mathrm{P}<0,05)$, enquanto um não apresentou $(\mathrm{P}<0,05)$. A estimativa combinada mostrou uma maior probabilidade de publicações de estudos que relatam resistência anti-helmíntica no valor de $0,59(95 \%: 0,8,0,47)$ do que estudos relatando tratamento anti-helmíntico eficaz. Os dados apresentaram baixa heterogeneidade $\left(\mathrm{I}^{2}=25 \%\right)$. A resistência anti-helmíntica a lactonas macrocíclicas é uma realidade. Há a necessidade de melhorar a metodologia dos estudos, pois é um problema para os trabalhos que envolvem revisóes sistemáticas e meta-análises (RS-MA).

Palavras-chave: Anti-helmínticos, nematódeos, ivermectina, moxidectina.

\section{Introduction}

Gastrointestinal nematodes (GINs) cause economic losses in livestock, especially when raised in extensive grazing systems (DEMELER et al., 2009). GINs are very common and their pathology negatively affects the health and welfare of infected animals, resulting in production losses (GEURDEN et al., 2015).

\footnotetext{
*Corresponding author: Raquel Abdallah da Rocha. Departamento de Zootecnia, Universidade Estadual de Ponta Grossa - UEPG, Av. Carlos Cavalcante, 4748, Uvaranas, CEP 84030-900, Ponta Grossa, PR, Brasil. e-mail: raroliveira@uepg.br
}

Their pathology affects growth in young animals, decreases milk production in adult dairy cows (RAVINET et al., 2016), causes gastrointestinal disorders, impairment of animal development, production losses, high costs of anthelmintics drugs and, in extreme cases, may result in death (CEZAR et al., 2008).

Broad-spectrum anthelmintic drugs have been the primary alternative to combat and control gastrointestinal infections for almost 40 years (GEURDEN et al., 2015). These drugs are divided into three main groups: benzimidazoles (BMs), 
imidazothiazoles (IMs) and macrocyclic lactones (MLs). MLs are widely used to control GINs in cattle, and this common practice has led to the development of anthelmintic resistance (AHR). Anthelmintic resistance to ivermectin was first reported in 1988, seven years after it was launched on the market (VAN WYK \& MALAN, 1988). AHR to moxidectin (LEATHWICK, 1995), doramectin (BORGSTEEDE et al., 2007) and eprinomectin (LOVERIDGE et al., 2003) were also reported years after they came onto the market. In New Zealand, Argentina, Brazil, the United States and Belgium, a prevalence of AHR against MLs has been reported, especially by Cooperia spp. (GRAEF et al., 2013).

In cattle herds, the preferred route of administration of anthelmintic drugs is via injection, because of its easy application and handling of the animals. However, comparisons of routes of administration (LEATHWICK \& MILLER, 2013; REINEMEYER \& CLEALE, 2002) have shown that this type of management can influence AHR (LEATHWICK \& LUO, 2017).

In recent years, several studies have focused on investigating the anthelmintic resistance of injectable MLs. While all these studies may provide valuable information, they sometimes describe contradictory findings. For example, some studies have described Cooperia spp. as resistant to MLs (CONDI et al., 2009; SUTHERLAND \& LEATHWICK, 2011), while others consider MLs effective (RODRÍGUEZ-VIVAS, et al., 2014). This clearly indicates the need for better evidence regarding the anthelmintic resistance of MLs administered via injection around the world.

One way to qualify and quantify such findings is through systematic review (SR) and meta-analysis (MA), which allow for the analysis and systematization of information. This type of procedure combines the findings of several studies to make a reproducible summary of their data (LOVATTO et al., 2007), providing the most substantive clinical evidence (MOHER et al., 2010), based on defined methods that guide the search and inclusion criteria (SARGEANT et al., 2006). A SR involves the critical assessment of sources of systematic bias that may influence the interpretation of results (HIGGINS et al., 2011).

The aim of this SR-MA was to identify, evaluate, and summarize primary literature reporting on the anthelmintic resistance of MLs injected into cattle. The rationale for this study was to generate information to help researchers make evidence based decisions regarding new directions for research into MLs and their routes of administration.

\section{Materials and Methods}

\section{Research question, definitions, and protocol}

This systematic review was conducted to ascertain the anthelmintic resistance of macrocyclic lactones administered via injection. The population species was defined as young cattle, i.e., calves, and buffalo were excluded. The interventions that involved AHR are listed in Table 1, adapted from Falzon et al. (2014).

Anthelmintic resistance was determined based on in vivo fecal egg count reduction tests (FECRT), necropsy examinations, in vitro larval development assays, or egg hatching assays; artificially induced infections were excluded. Relevant comparators were publications that reported one or more groups receiving treatment only with macrocyclic lactones in different dosages. All the search terms are listed in Table 2.

Table 1. Definitions of interventions considered in this review.

\begin{tabular}{|c|c|}
\hline Acronym & Definition \\
\hline \multirow{11}{*}{ Interventions } & $\begin{array}{l}\text { Under-dosing: This occurs when the cattle receive less than the optimal anthelmintic dosage. This may occur for various reasons, } \\
\text { including inaccurate weight estimation, or incorrect method of administration }\end{array}$ \\
\hline & Route of administration: Anthelmintic drugs can be administered orally, pour on or subcutaneously. \\
\hline & $\begin{array}{l}\text { Long-acting/persistent anthelmintic drugs: Anthelmintic drugs that have a persistent action, either because of their lipophilic } \\
\text { nature, or because of their formulation. }\end{array}$ \\
\hline & Timing of anthelmintic treatment: The timing of treatment relative to certain stages of production or management stages. \\
\hline & Mixed-species grazing: Simultaneous grazing of cattle with other species. \\
\hline & Rotational grazing: The practice of moving grazing livestock between pastures (often called paddocks) as needed or on a regular basis. \\
\hline & $\begin{array}{l}\text { Strategic treatment: Anthelmintic treatments of the group that are aimed at identified potential periods of risk based on fecal egg } \\
\text { count monitoring or clinical signs. }\end{array}$ \\
\hline & $\begin{array}{l}\text { Pasture management: Grazing management strategies that reduce reliance on anthelmintics by decreasing the cattle's exposure to } \\
\text { parasite burdens on pasture. }\end{array}$ \\
\hline & Rotation of anthelmintics: Changing the drug class used on the farm every one to two years. \\
\hline & $\begin{array}{l}\text { Drench-and-shift: Treating the animals with anthelmintics, and then moving them immediately to pasture considered as free of, } \\
\text { or with a low level of, contamination with gastro-intestinal nematodes, to reduce risk of re-infection. }\end{array}$ \\
\hline & $\begin{array}{l}\text { Drench gun calibration: Emptying of the drench gun into a graduated measure device and adjusting to ensure that the drench } \\
\text { gun is delivering the correct amount of anthelmintic drug. }\end{array}$ \\
\hline
\end{tabular}


Table 2. Population and outcome search term strings used for the final search in the systematic review.

\begin{tabular}{ll}
\hline \multicolumn{1}{c}{ Acronym } & \multicolumn{1}{c}{ Search string } \\
\hline Population & ("cattle" OR "calves") ("beef” OR "dairy") \\
Outcome & (anthelmintic OR "macrocyclic lactone" OR ivermectin OR moxidectin OR doramectin OR abamectin) AND \\
& (gastrointestinal OR internal) AND (parasite OR nematode OR worms OR worming) AND (resistance OR \\
& resistant) AND (efficacy OR effectiveness) AND (faecal egg count reduction test OR FECRT) AND (route of \\
& administration" OR "injectable formulation") AND ("natural infections") \\
\hline
\end{tabular}

\section{Literature search strategy}

An electronic search with specific search terms was developed and implemented between February and May 2017 (Table 2). A systematic literature search was conducted in PubMed (Medline), Web of Science, and Academic Google, for publications made available through the State University of Ponta Grossa by the CAPES portal (Periodicos da CAPES). The research period was from 1996 to 2016. A manual search of reference reviews was conducted on the development of AHR in cattle (SUTHERLAND \& LEATHWICK, 2011). The data were extracted from tables listing results.

\section{Study inclusion criteria and screening}

A single investigator independently screened all the publications by title and abstract, followed by a full text evaluation of relevant publications. After the studies were identified, they were carefully evaluated as to their quality and importance. In this step, an analysis was made of the information contained in each study regarding experimental design, treatments and analyzed data. The main criterion for inclusion of the articles in the meta-analysis was the percent reduction in egg output following anthelmintic treatment in cattle to enable an analysis of the resistance to these drugs. No limits were applied for language, and non-English papers were translated.

Initially, abstracts that did not mention percent reduction values, articles involving other animal species, and studies that used homeopathic products were excluded. Then, after selecting the studies considered eligible, those that did not use MLs (imidazothiazoles, benzimidazoles, benzoylphenylurea, salicylanilides/ substituted phenols and combinations), studies involving adult cattle (more than 15 months old), studies that used more than one route of application (injectable and oral; injectable and pour on) and studies that used drug combination were excluded.

\section{Qualitative and quantitative data extraction}

A single independent investigator extracted the data and inserted them into a Microsoft Excel (2010) spreadsheet. Extracted information included: (i) study characteristics (author, year, periodical, country and institutional affiliation); (ii) farm characteristics (beef or dairy cattle); (iii) animal characteristics (age, breed, type, number of animals in each treatment); (iv) type of outcome measurement (percent reduction (FECRT)), (v) anthelmintic dosage and route of administration, (vi) active ingredient used (ivermectin, moxidectin or doramectin), and (vii) gastrointestinal parasite species.

\section{Methodological assessment of bias}

Risk of systematic bias was assessed independently by one investigator in all the relevant full-text publications, and separate guidelines were considered for experimental studies. Domains considered for the experimental trials included: (i) random sequence generation; (ii) random allocation concealment; (iii) blinding of outcome assessment; (iv) incomplete outcome data; and (v) selective reporting (HIGGINS et al., 2011). Each of these domains was classified as having a low, high, or unclear risk of producing biased results, following pre-set definitions (CARVALHO et al., 2013).

\section{Meta-analysis}

Studies were included in the quantitative summary providing they met all the following criteria: (i) low risk of producing biased results; (ii) AHR measured using a methodology defined a priori in our protocol. The forest plot was created as proposed by Neyeloff et al. (2012), using Microsoft Excel (2007). The plot containing the six studies gave a graphical representation in which each square represented a study, with confidence intervals of effect size at $95 \%$ represented by the horizontal lines. The central line represented no difference between the interventions and separated the graph into studies that reported anthelmintic resistance to drugs (left side) and efficacy of drugs (right side). Horizontal lines crossing the central tendency line indicated no difference between interventions $(P>0.05)$. The last line of the graph presented the summarized value. Statistical heterogeneity was assessed using the $r^{2}$ statistic, which describes the proportion of total variation across studies that is attributable to heterogeneity (inter-study variation) rather than chance (intra-study variation), and the magnitude was interpreted as low $\left(I^{2}<25 \%\right)$, medium $\left(I^{2}=25\right.$ to $\left.50 \%\right)$, or high heterogeneity $\left(P^{2}>50 \%\right)$ (HIGGINS et al., 2003). Analyses were performed to determine whether certain publications had substantial impact (weight \%) and Odds Ratios.

\section{Results}

\section{Literature search, abstract, and full-text screening}

The electronic database search provided a total of 2914 citations. After the exclusion of duplicates and screening of titles and abstracts, 1504 citations remained. After this step, only 80 full-text publications were evaluated further for relevance; of these, 13 were included in the risk of systematic bias assessment and data extraction (Figure 1). 


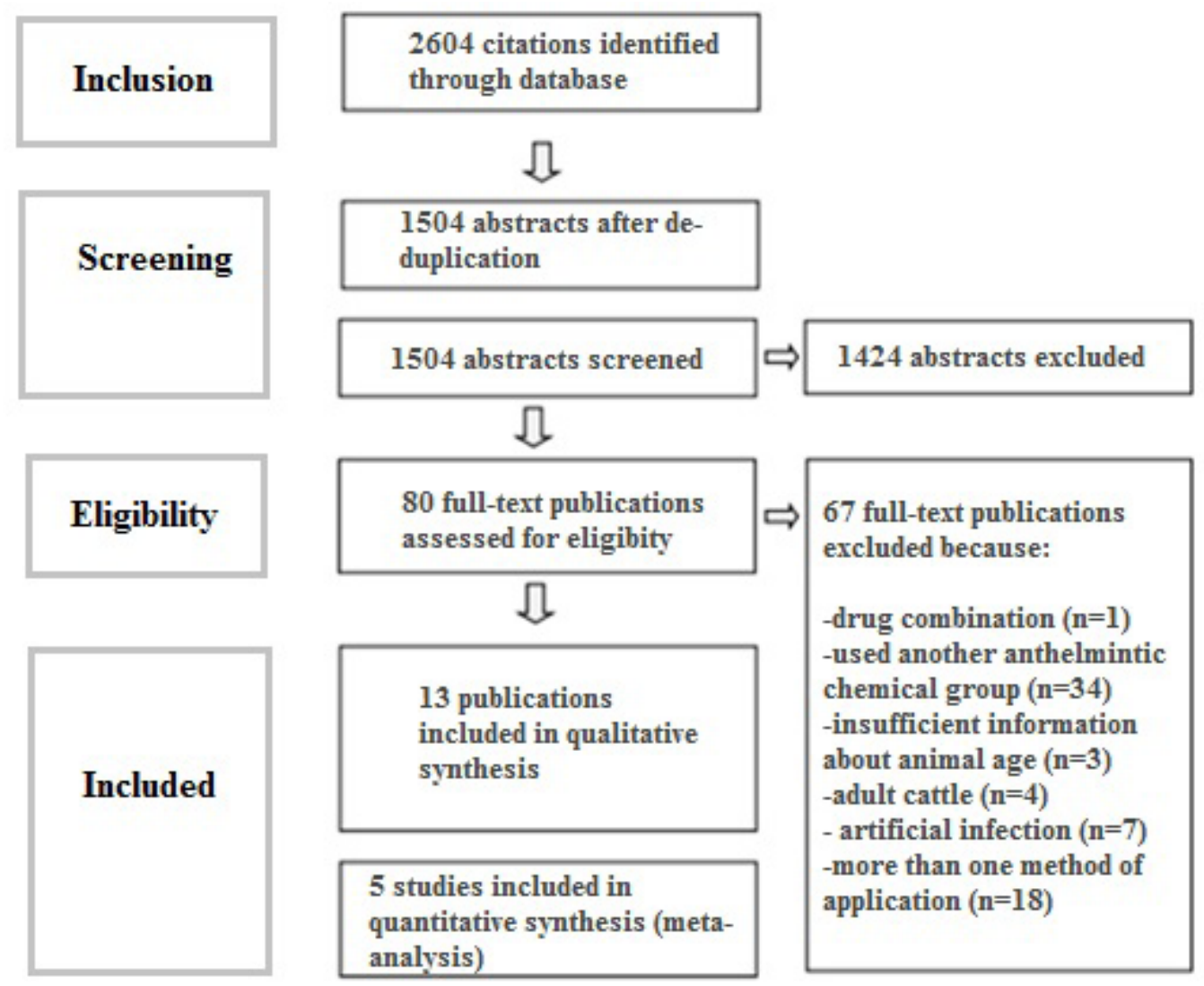

Figure 1. Flow diagram following PRISMA guidelines (Moher et al., 2010), showing the total number of records identified and the number of records filtered at each stage of the selection process from the systematic review and meta-analysis.

\section{Risk of systematic bias and data extraction}

Thirteen publications were included in the risk of bias. The main characteristics considered for the experimental trials are described in Table 3 and include: (i) country, (ii) reported risk and protective factors, (iii) anthelmintic drug, (iv) outcome measurement, (v) type of GIN recovered, and (vi) route of administration.

The studies included in the systematic review were carried out in Mexico ( $n=3)$, Brazil ( $n=3)$, Chile ( $n=2)$, Cuba ( $n=1)$, Canada $(\mathrm{n}=1)$, Belgium $(\mathrm{n}=2)$, Germany $(\mathrm{n}=1)$ and United Kingdom $(\mathrm{n}=1)$. Fourteen risk and protective factors were described: frequency of treatment $(n=6)$, mixed-species grazing $(n=2)$, climate $(n=3)$, location $(n=4)$, farm type $(n=6)$, last dewormed $(n=4)$, season grazing $(n=2)$, average temperature $(n=1)$, pasture rotation $(n=1)$ and rotation between anthelmintics $(n=1)$. The anthelmintic drug classes investigated included only the macrocyclic lactones ivermectin $(n=9)$, doramectin $(n=2)$ and moxidectin $(n=5)$. Anthelmintic resistance was determined using only a FECRT $(\mathrm{n}=13)$. The route of administration was only injectable $(\mathrm{n}=13)$ in different doses, $0.2 \mathrm{mg} / \mathrm{Kg}(\mathrm{n}=11), 1 \mathrm{mg} / \mathrm{Kg}(\mathrm{n}=1)$ and not specified $(n=1)$. Parasite species investigated included Cooperia spp. $(\mathrm{n}=12)$, Trichostrongylus spp. $(\mathrm{n}=7)$, Haemonchus spp. $(\mathrm{n}=7)$, Ostertagia spp. $(\mathrm{n}=5)$, Oesophagostomum spp. $(\mathrm{n}=1)$, Strongyloides spp. $(\mathrm{n}=1)$, Bunostomum spp. $(\mathrm{n}=1)$, Trichuris spp. $(\mathrm{n}=1)$ and Nematodirus spp. $(\mathrm{n}=1)$.
Table 4 summarizes the bias classifications for the studies included in the SR. Unclear (i.e. not reported, or unable to assess) or low risk of selection bias based on random sequence generation were found in (5/13) and (8/13) of the studies, respectively. Unclear, high or low risk of performance bias based on random allocation concealment were identified in (5/13) and (1/13) and (7/13) of the studies, respectively. Unclear, high or low risk of performance bias based on blinding of outcome assessment were identified in $(2 / 13)$ and (4/13) and (7/16) of the studies, respectively. High or low risk of performance bias based on incomplete outcome data were identified in (1/13) and (12/13) of the studies, respectively. All the observational studies were found to have a low risk of detection bias on selective outcome reporting.

\section{Meta-analysis}

Only studies that presented low risk of selection bias based on random sequence generation, random allocation concealment, blinding of outcome assessment, incomplete outcome data and selective outcome reporting were included in the quantitative synthesis $(n=5)$. The studies selected here were published between 1992 and 2012: (i) Condi et al. (2009); (ii) Canul-Ku et al. (2012); (iii) Geurden et al. (2004); (iv) Ranjan et al. (1992) and (v) Sievers and Fuentealba (2003). The outcome was calculated based on the number of sample sizes and the number of events, where the sample sizes were the total number of cattle treated 
Table 3. Descriptive characteristics of the 13 observational studies included in the systematic review.

\begin{tabular}{|c|c|c|c|c|c|c|}
\hline $\begin{array}{c}\text { Study } \\
\text { (author and year) }\end{array}$ & Country & $\begin{array}{c}\text { Risk and protective factors } \\
\text { reported }\end{array}$ & $\begin{array}{c}\text { Anthelmintic } \\
\text { drug }\end{array}$ & $\begin{array}{c}\text { Outcome } \\
\text { measurement }\end{array}$ & Type of GIN recovered & $\begin{array}{c}\text { Route of } \\
\text { administration }\end{array}$ \\
\hline $\begin{array}{c}\text { Alonso-Diaz et al. } \\
(2015)\end{array}$ & Mexico & $\begin{array}{c}\text { Climate; farm type; last } \\
\text { dewormed }\end{array}$ & Ivermectin & FECRT & $\begin{array}{c}\text { Cooperia sp.; } \\
\text { Haemonchus sp.; } \\
\text { Strongyloides sp.; and } \\
\text { Oesophagostomum sp. }\end{array}$ & $\begin{array}{l}\text { Injectable } \\
0.2 \mathrm{mg} / \mathrm{Kg}\end{array}$ \\
\hline Arantes et al. (1995) & Brazil & Not specified & Ivermectin & FECRT & $\begin{array}{c}\text { Haemonchus } \\
\text { placei; Trichostrongylus } \\
\text { axei; T. colubriformis; } \\
\text { Bunostomum } \\
\text { phlebotomum; } \\
\text { Cooperia punctata; } \\
\text { Oesophagostomum } \\
\text { radiatum }\end{array}$ & $\begin{array}{l}\text { Injectable } \\
0.2 \mathrm{mg} / \mathrm{Kg}\end{array}$ \\
\hline $\begin{array}{l}\text { Canul-Ku et al. } \\
\text { (2012) }\end{array}$ & Mexico & $\begin{array}{l}\text { Climate; location; average } \\
\text { temperature; farm type; } \\
\text { frequency of treatment }\end{array}$ & Ivermectin & FECRT & $\begin{array}{l}\text { Haemonchus sp.; } \\
\text { Ostertagia sp.; } \\
\text { Trichostrongylus sp.; } \\
\text { Cooperia sp. }\end{array}$ & $\begin{array}{l}\text { Injectable } \\
0.2 \mathrm{mg} / \mathrm{Kg}\end{array}$ \\
\hline Condi et al. (2009) & Brazil & $\begin{array}{l}\text { Farm type; mixed-species } \\
\text { grazing; frequency of } \\
\text { treatment; rotation of } \\
\text { anthelmintic drug }\end{array}$ & Moxidectin & FECRT & $\begin{array}{l}\text { Cooperia sp.; } \\
\text { Oesophagostumum sp.; } \\
\text { Trichuris sp. }\end{array}$ & $\begin{array}{l}\text { Injectable } \\
0.2 \mathrm{mg} / \mathrm{Kg}\end{array}$ \\
\hline $\begin{array}{l}\text { El-Abdellati et al. } \\
\qquad(2010)\end{array}$ & $\begin{array}{l}\text { Belgium and } \\
\text { Germany }\end{array}$ & $\begin{array}{l}\text { Frequency of treatment; } \\
\text { season grazing }\end{array}$ & $\begin{array}{l}\text { Macrocyclic } \\
\text { Lactone }\end{array}$ & FECRT & Cooperia oncophora & $\begin{array}{c}\text { Injectable } \\
\text { Not specified }\end{array}$ \\
\hline $\begin{array}{l}\text { Geurden et al. } \\
\qquad(2004)\end{array}$ & Belgium & season grazing & Moxidectin & FECRT & $\begin{array}{l}\text { Ostertagia sp.; Cooperia } \\
\text { sp.; Trichostrongylus sp.; } \\
\text { Oesophagostomum sp. }\end{array}$ & $\begin{array}{l}\text { Injectable } \\
1 \mathrm{mg} / \mathrm{Kg}\end{array}$ \\
\hline Llorens et al. (2014) & Cuba & Last dewormed & Ivermectin & FECRT & $\begin{array}{l}\text { Haemonchus sp.; } \\
\text { Trichostrongylus sp.; } \\
\text { Bunustomun sp.; }\end{array}$ & $\begin{array}{l}\text { Injectable } \\
0.2 \mathrm{mg} / \mathrm{Kg}\end{array}$ \\
\hline Mena et al. (2008) & Mexico & $\begin{array}{c}\text { Mixed-species grazing; last } \\
\text { dewormed }\end{array}$ & Ivermectin & FECRT & $\begin{array}{l}\text { Cooperia sp.; } \\
\text { Oesophagostomum sp.; } \\
\text { Haemonchus sp. }\end{array}$ & $\begin{array}{l}\text { Injectable } \\
0.2 \mathrm{mg} / \mathrm{Kg}\end{array}$ \\
\hline Rangel et al. (2005) & Brazil & $\begin{array}{l}\text { Farm type; climate; location; } \\
\text { last dewormed; frequency of } \\
\text { treatment; species grazing }\end{array}$ & $\begin{array}{l}\text { Moxidectin; } \\
\text { ivermectin } \\
\text { and } \\
\text { doramectin }\end{array}$ & FECRT & $\begin{array}{l}\text { Cooperia sp. and } \\
\text { Haemonchus sp. }\end{array}$ & $\begin{array}{l}\text { Injectable } \\
0.2 \mathrm{mg} / \mathrm{Kg}\end{array}$ \\
\hline Ranjan et al. (1992) & Canada & Farm type & Moxidectin & FECRT & $\begin{array}{l}\text { Ostertagia sp.; } \\
\text { Trichostrongylus sp.; } \\
\text { Cooperia sp. and } \\
\text { Nematodirus sp. }\end{array}$ & $\begin{array}{l}\text { Injectable } \\
0.2 \mathrm{mg} / \mathrm{Kg}\end{array}$ \\
\hline $\begin{array}{c}\text { Sievers } \& \\
\text { Fuentealba }(2003)\end{array}$ & Chile & Farm type and location & $\begin{array}{l}\text { Ivermectin; } \\
\text { doramectin } \\
\quad \text { and } \\
\text { moxidectin }\end{array}$ & FECRT & $\begin{array}{l}\text { Cooperia sp.; } \\
\text { Ostertagia sp.; and } \\
\text { Trichostrongylus sp. }\end{array}$ & $\begin{array}{l}\text { Injectable } \\
0.2 \mathrm{mg} / \mathrm{Kg}\end{array}$ \\
\hline $\begin{array}{l}\text { Sievers \& Alocilla } \\
(2007)\end{array}$ & Chile & $\begin{array}{c}\text { Farm location and frequency } \\
\text { of treatment }\end{array}$ & Ivermectin & FECRT & $\begin{array}{l}\text { Ostertagia sp.; } \\
\text { Cooperia sp. and } \\
\text { Trichostrongylus sp. }\end{array}$ & $\begin{array}{l}\text { Injectable } \\
0.2 \mathrm{mg} / \mathrm{Kg}\end{array}$ \\
\hline $\begin{array}{c}\text { Stafford \& Coles } \\
(1999)\end{array}$ & $\begin{array}{l}\text { United } \\
\text { Kingdom }\end{array}$ & $\begin{array}{c}\text { Frequency of treatment and } \\
\text { pasture rotation }\end{array}$ & Ivermectin & FECRT & Cooperia sp. & $\begin{array}{l}\text { Injectable } \\
0.2 \mathrm{mg} / \mathrm{Kg}\end{array}$ \\
\hline
\end{tabular}


Table 4. Methodological quality assessment for risk of systematic bias (classified as low, high or unclear) of the 13 publications included in the systematic review.

\begin{tabular}{|c|c|c|c|c|c|}
\hline $\begin{array}{c}\text { Study } \\
\text { (author and year) }\end{array}$ & $\begin{array}{c}\text { Random sequence } \\
\text { generation }\end{array}$ & $\begin{array}{l}\text { Random allocation } \\
\text { concealment }\end{array}$ & $\begin{array}{c}\text { Blinding of } \\
\text { outcome assessment }\end{array}$ & $\begin{array}{c}\text { Incomplete } \\
\text { outcome data }\end{array}$ & $\begin{array}{c}\text { Selective outcome } \\
\text { reporting }\end{array}$ \\
\hline Alonso-Diaz et al. (2015) & Unclear & Unclear & High & Low & Low \\
\hline Arantes et al. (1995) & Low & Unclear & Low & Low & Low \\
\hline Canul-Ku et al. (2012) & Low & Low & Low & Low & Low \\
\hline Condi et al. (2009) & Low & Low & Low & Low & Low \\
\hline El-Abdellati et al. (2010) & Low & Low & Unclear & High & Low \\
\hline Geurden et al. (2004) & Low & Low & Low & Low & Low \\
\hline Llorens et al. (2014) & Unclear & Unclear & High & Low & Low \\
\hline Mena et al. (2008) & Unclear & Low & High & Low & Low \\
\hline Rangel et al. (2005) & Unclear & Unclear & Unclear & Low & Low \\
\hline Ranjan et al. (1992) & Low & Low & Low & Low & Low \\
\hline Sievers \& Fuentealba (2003) & Low & Low & Low & Low & Low \\
\hline Sievers \& Alocilla (2007) & Low & High & Low & Low & Low \\
\hline Stafford \& Coles (1999) & Unclear & Unclear & High & Low & Low \\
\hline
\end{tabular}

\section{Study Weight Odds Ratio}

IV, Random, $95 \% \mathrm{Cl}$

$\begin{array}{ccl}\text { Condi et al. (2009) } & 4.39 \% & 0(0 ; 0) \\ \text { Canul-Ku et al. (2012) } & 15.38 \% & 0.23(0.13 ; 0.59) \\ \text { Geurden et al. (2004) } & 12.08 \% & 0.54(0.22 ; 1.31) \\ \text { Ranjan et al. (1992) } & 2.19 \% & 2(0 ; 0) \\ \text { Sievers et al. (2003) } & 65.93 \% & 0.20(0.05 ; 0.46) \\ \begin{array}{c}\text { Total (95\%CL) } \\ \quad \mathbf{I}^{2}=\mathbf{2 5 \%}\end{array} & 0.59(0.08 ; 0.47) \\ \quad 100 \% & & -1\end{array}$

Figure 2. Forest plot of five studies included in a meta-analysis evaluating the association between studies with anthelmintic resistance in cattle and the studies with efficacy of anthelmintic drugs.

with anthelmintic drugs, and the events were the number of samples whose percent efficacy was higher than 95\%, since a drug is considered effective when the percent reduction is higher than 95\% after treatment (ARESKOG et al., 2013). The forest plot (Figure 2) shows four studies with AHR $(\mathrm{P}<0.05)$, and only one study without AHR $(\mathrm{P}<0.05)$. The last line of the graph shows the summarized value (MA). The pooled estimate indicated 0.59 (95\% CI: $0.08,0.47)$ times higher odds of studies with AHR than of studies reporting the efficacy of anthelmintic treatment, with significant and substantially low heterogeneity $\left(I^{2}=25 \%\right.$; test for heterogeneity).

\section{Discussion}

This SR-MA enabled us to identify and summarize the published evidence currently available in studies aimed at discovering AHR in cattle. A low level of significant heterogeneity was observed in the pooled estimate. This was expected, since all the studies included in the MA were experimental ones, involving similar characteristics; for example, all the studies included on the meta-analysis used macrocyclic lactone as the anthelmintic drug, administered via injection only to young cattle - the research population, and the diagnostic tool employed to determine AHR was the FECRT. Observational studies should not be included in a MA, given that they are subject to several systematic biases (LEAN et al., 2009). A minimum of ten studies per meta-analysis for regression is usually recommended (HIGGINS et al., 2003). However, in this meta-analysis we were unable to carry out subgroup or meta-regression analysis because of the limited number of studies involved in our quantitative analysis.

The route of administration most commonly found in this SR was injection, so it was used as the selection criterion for the inclusion of articles in the meta-analysis. This route is often used mainly because it is easy to administer and requires infrequent application in animals that may be difficult to handle. Therefore, 
the injectable and pour-on products of the ML family are the most widely used in cattle (SUTHERLAND \& LEATHWICK, 2011). Studies on horses and sheep comparing different routes of administration of anthelmintics have demonstrated a correlation with anthelmintic efficacy (GOKBULUT et al., 2010; LLOBERAS et al., 2012). Leathwick \& Miller (2013) showed the efficacy and plasma profiles of the ML moxidectin administered to cattle by the oral, injection and pour-on routes, demonstrating that the mean efficacy of these treatments can differ significantly. Even with the high bioavailability provided by the injectable route, this meta-analysis revealed a high probability of finding studies that showed anthelmintic resistance against gastrointestinal nematodes using macrocyclic lactones as the anthelmintic drug. AHR against commercially available classes of drugs administered via different routes is an emerging problem throughout the world (DEMELER et al., 2009).

Most of the studies included in this SR and MA reported using a dosage of $0.2 \mathrm{mg} / \mathrm{Kg}$ (ALONSO-DIAZ et al. 2015; ARANTES et al., 1995; CANUL-KU et al., 2012; CONDI et al., 2009; LLORENS et al., 2014; MENA et al., 2008; RANGEL et al., 2005; RANJAN et al., 1992; SIEVERS \& FUENTEALBA, 2003; SIEVERS \& ALOCILLA, 2007; STAFFORD \& COLES, 1999). Correct dosing in the application of anthelmintic drugs may prevent the development of AHR (LESPINE et al., 2012), but farmers sometimes treat animals at dose rate below those recommended by the manufacturer. Suboptimal dosing (LEATHWICK \& LUO, 2017) and underdosing (MACIEL et al., 1996) of anthelmintic drugs will lead to the development of AHR in cattle. The application of mean doses with standard deviations in order to calculate the general change in gene frequency showed that resistance occurred more often due to lower mean doses and higher variability of dosing (LEATHWICK \& LUO, 2017).

Macrocyclic lactones are broad-spectrum endectocides widely used in domestic animals (GEARY, 2005). AHR to MLs is widespread around the world in cattle herds (KAPLAN, 2004). The MLs available for application in cattle are presented in different formulations, with different active ingredients, concentrations and associations, and the predominant anthelmintic found in this SR and MA was ivermectin. The nematode genus Cooperia was the one most frequently identified in this study, and the resistance of this genus to ivermectin is relatively common and widespread (KAPLAN \& VIDYASHANKAR, 2012). This finding has been reported by several authors in Argentina (SUAREZ \& CRISTEL, 2007), and in New Zealand, where most cases of resistance to ML involve this genus (SUTHERLAND \& LEATHWICK, 2011). Because of this parasite's low pathogenicity (COOP et al., 1979), insufficient importance has been given to its AHR, which may have led to high levels of resistance (SUTHERLAND \& LEATHWICK, 2011). Ostertagia spp. have been reported in many studies. This genus is considered highly pathogenic, so farmers should be particularly careful to employ effective cattle deworming strategies.

The method used in all the studies selected for SR and MA was FECRT. It was used as a criterion of inclusion because it is considered relatively easy to perform (MAINGI et al., 1998), and most of the studies adopted this technique. Another benefit of FECRT is the high correlation between the worm burden and the values obtained through this method (BRICARELLO et al., 2007). However, the necropsy test is also reported in many studies (YAZWINSKI et al., 2013; VERCRUYSSE et al., 2000; LOPES et al., 2013), although it involves numerous steps and is only performed after the death of an animal (COUMENDOUROS et al., 2003). This demonstrates that the use of the simpler and cheaper method (FECRT) may be more feasible, but there is currently no agreement about the preferred method for the diagnosis of AHR (FALZON et al., 2014).

\section{Conclusions}

The results of this SR-MA provide synthesized evidence that anthelmintic resistance to injectable MLs is a reality in several continents, highlighting the difficulties of controlling gastrointestinal nematodes in cattle. This SR-MA also found marginal evidence to support the statement that articles reporting on this methodology may have reached the point of saturation, as demonstrated by our findings. Lastly, we argue for the need to improve methodological reporting in studies, which is a problem that has also been reported by many authors whose work involves SR-MA.

\section{Acknowledgements}

This study was financed in part by the Coordenação de Aperfeiçoamento de Pessoal de Nível Superior - Brasil (CAPES) - Finance 001.

\section{References}

Alonso-Díaz MA, Arnaud-Ochoa RA, Becerra-Nava R, Torres-Acosta JFJ, Rodríguez-Vivas RI, Quiroz-Romero RH. Frequency of cattle farms with ivermectin resistant gastrointestinal nematodes in Veracruz, Mexico. Vet Parasitol 2015; 212(3-4): 439-443. http://dx.doi.org/10.1016/j. vetpar.2015.07.023. PMid:26238656.

Arantes GJ, Silva CR, Costa JO, Marra DB. Atividade anti-helmíntica da ivermectina a $1 \%$ (solução injetável), no tratamento de bezerros naturalmente infectados com nematóides gastrintestinais. Rev Bras Parasitol Vet 1995; 4(2): 113-116.

Areskog M, Ljungström B, Höglund J. Limited efficacy of pour-on anthelmintic treatment of cattle under Swedish field conditions. Int $J$ Parasitol Drugs Drug Resist 2013; 3: 129-134. http://dx.doi.org/10.1016/j. ijpddr.2013.06.002. PMid:24533302.

Borgsteede FH, Dercksen DD, Huijbers R. Doramectin and albendazole resistance in sheep in The Netherlands. Vet Parasitol 2007; 144(1-2): 180183. http://dx.doi.org/10.1016/j.vetpar.2006.09.031. PMid:17113232.

Bricarello PA, Zaros LG, Coutinho LL, Rocha RA, Kooyman FNJ, De Vries E, et al. Field study on nematode resistance in Nelore-breed cattle. Vet Parasitol 2007; 148(3-4): 272-278. http://dx.doi.org/10.1016/j. vetpar.2007.06.013. PMid:17659839.

Canul-Ku HL, Rodríguez-Vivas RI, Torres-Acosta JFJ, Aguilar-Caballero AJ, Pérez-Cogollo LC, Ojeda-Chi MM. Prevalence of cattle herds with ivermectin resistant nematodes in the hot sub-humid tropics of Mexico. Vet Parasitol 2012; 183(3-4): 292-298. http://dx.doi.org/10.1016/j. vetpar.2011.07.029. PMid:21831526. 
Carvalho APV, Silva V, Grande AJ. Avaliação do risco de viés de ensaios clínicos randomizados pela ferramenta da colaboraçáo Cochrane. Diagn Tratamento 2013; 18(1): 38-44.

Cezar AS, Catto JB, Bianchin I. Controle alternativo de nematódeos gastrintestinais dos ruminantes: atualidade e perspectivas. Cienc Rural 2008; 38(7): 2083-2091. http://dx.doi.org/10.1590/S0103-84782008000700048.

Condi GK, Soutello RGV, Amarante AFT. Moxidectin-resistant nematodes in cattle in Brazil. Vet Parasitol 2009; 161(3-4): 213-217. http://dx.doi. org/10.1016/j.vetpar.2009.01.031. PMid:19251366.

Coop RL, Sykes AR, Angus KW. The pathogenicity of daily intakes of Cooperia oncophora larvae in growing calves. Vet Parasitol 1979; 5(2-3): 261-269. http://dx.doi.org/10.1016/0304-4017(79)90015-3.

Coumendouros K, Tancredi IP, Scott FB, Martins IVF, Sant'Anna FB, Grisi L. Eficácia anti-helmíntica da eprinomectina no controle de nematóides gastrintestinais de bovinos. Rev Bras Parasitol Vet 2003; 12(3): 121-124.

Demeler J, Van Zeveren MJ, Kleinschmidt N, Vercruysse J, Höglund J, Koopmann R, et al. Monitoring the efficacy of ivermectin and albendazole against gastro intestinal nematodes of cattle in Northern Europe. Vet Parasitol 2009; 160(1-2): 109-115. http://dx.doi.org/10.1016/j. vetpar.2008.10.030. PMid:19062191.

El-Abdellati A, Charlier J, Geldhof P, Levecke B, Demeler J, von SamsonHimmelstjerna G, et al. The use of a simplified faecal egg count reduction test for assessing anthelmintic efficacy on Belgian and German cattle farms. Vet Parasitol 2010; 169(3-4):352-357. http://dx.doi.org/10.1016/j. vetpar.2010.01.015. PMid:20149547.

Falzon LC, O’Neill TJ, Menzies PI, Peregrine AS, Jones-Bitton A, van Leeuwen J, et al. A systematic review and meta-analysis of factors associated with anthelmintic resistance in sheep. Prev Vet Med 2014; 117(2): 388-402. http://dx.doi.org/10.1016/j.prevetmed.2014.07.003. PMid:25059197.

Geary TG. Ivermectin 20 years on: Maturation of a wonder drug. Trends Parasitol 2005; 21(11): 530-532. http://dx.doi.org/10.1016/j. pt.2005.08.014. PMid:16126457.

Geurden T, Chartier C, Fanke J, di Regalbono AF, Traversa D, von Samson-Himmelstjerna G, et al. Anthelmintic resistance to ivermectin and moxidectin in gastrointestinal nematodes of cattle in Europe. Int J Parasitol Drugs Drug Resist 2015; 5(3): 163-171. http://dx.doi. org/10.1016/j.ijpddr.2015.08.001. PMid:26448902.

Geurden T, Claerebout E, Deroover E, Vercruysse J. Evaluation of the chemoprophylactic efficacy of $10 \%$ long acting injectable moxidectin against gastrointestinal nematode infections in calves in Belgium. Vet Parasitol 2004; 120(4): 331-338. http://dx.doi.org/10.1016/j.vetpar.2004.01.016. PMid:15063943.

Gokbulut C, Cirak VY, Senlik B, Aksit D, Durmaz M, McKellar QA. Comparative plasma disposition, bioavailability and efficacy of ivermectin following oral and pour-on administration in horses. Vet Parasitol 2010; 170(1-2): 120-126. http://dx.doi.org/10.1016/j.vetpar.2010.01.041. PMid:20181429.

Graef J, Claerebout E, Geldhof P. Anthelmintic resistance of gastrointestinal cattle nematodes. Vlaams Diergen Tijds 2013; 82: 113-123.

Higgins JPT, Altman DG, Gotzsche PC, Jüni P, Moher D, Oxman $\mathrm{AD}$, et al. The Cochrane collaboration's tool for assessing risk of bias in randomized trials. BMJ 2011; 343: d5928. http://dx.doi.org/10.1136/ bmj.d5928. PMid:22008217.

Higgins JPT, Thompson SG, Deeks JJ, Altman DG. Measuring inconsistency in meta-analyses. BMJ 2003; 327(7414): 557-560. http:// dx.doi.org/10.1136/bmj.327.7414.557. PMid:12958120.
Kaplan RM, Vidyashankar AN. An inconvenient truth: Global worming and anthelmintic resistance. Vet Parasitol 2012; 186(1-2): 70-78. http:// dx.doi.org/10.1016/j.vetpar.2011.11.048. PMid:22154968.

Kaplan RM. Drug resistance in nematodes of veterinary importance: a status report. Trends Parasitol 2004; 20(10): 477-481. http://dx.doi. org/10.1016/j.pt.2004.08.001. PMid:15363441.

Lean IJ, Rabiee AR, Duffield TF, Dohoo IR. Invited review: use of metaanalysis in animal health and reproduction: methods and applications. $J$ Dairy Sci 2009; 92(8): 3545-3565. http://dx.doi.org/10.3168/jds.20092140. PMid:19620636.

Leathwick DM, Luo D. Managing anthelmintic resistance-Variability in the dose of drug reaching the target worms influences selection for resistance? Vet Parasitol 2017; 243: 29-35. http://dx.doi.org/10.1016/j. vetpar.2017.05.032. PMid:28807306.

Leathwick DM, Miller CM. Efficacy of oral, injectable and pour-on formulations of moxidectin against gastrointestinal nematodes in cattle in New Zealand. Vet Parasitol 2013; 191(3-4): 293-300. http://dx.doi. org/10.1016/j.vetpar.2012.09.020. PMid:23063773.

Leathwick DM. A case of moxidectin failing to control ivermectin resistant Ostertagia species in goats. Vet Rec 1995; 136(17): 443-444. http://dx.doi.org/10.1136/vr.136.17.443. PMid:7631480.

Lespine A, Chartier C, Hoste H, Alvinerie M. Endectocides in goats: Pharmacology, efficacy and use conditions in the context of anthelmintics resistance. Small Rumin Res 2012; 103(1): 10-17. http://dx.doi.org/10.1016/j. smallrumres.2011.10.013.

Lloberas M, Alvarez L, Entrocasso C, Virkel G, Lanusse C, Lifschitz A. Measurement of ivermectin concentrations in target worms and host gastrointestinal tissues: influence of the route of administration on the activity against resistant Haemonchus contortus in lambs. Exp Parasitol 2012; 131(3): 304-309. http://dx.doi.org/10.1016/j.exppara.2012.04.014. PMid:22575734.

Llorens IYG, Ponce JDM, Suárez JCM, Carrazana BM, Méndez DG. Eficacia antihelmíntica del Labiomec ${ }^{\circledR}$ (Ivermectina 1\%) en rebaños bovinos de Camagüey. Rev Salud Anim 2014; 36(1): 58-61.

Lopes WDZ, Santos TR, Sakamoto CAM, Lima RCA, Valarelli RL, Paiva P, et al. Persistent efficacy of $3.5 \%$ doramectin compared to $3.15 \%$ ivermectin against gastrointestinal nematodes in experimentallyinfected cattle in Brazil. Res Vet Sci 2013; 94(2): 290-294. http://dx.doi. org/10.1016/j.rvsc.2012.09.022. PMid:23102648.

Lovatto PA, Lehnen CR, Andretta I, Carvalho AD, Hauschild L. Metaanálise em pesquisas científicas: enfoque em metodologias. Rev Bras Zootec 2007; 36(suppl): 285-294. http://dx.doi.org/10.1590/S151635982007001000026.

Loveridge B, McArthur M, McKenna PB, Mariadass B. Probable multigeneric resistance to macrocyclic lactone anthelmintics in cattle in New Zealand. N Z Vet J 2003; 51(3): 139-141. http://dx.doi.org/10.1 080/00480169.2003.36353. PMid:16032313.

Maciel S, Giménez AM, Gaona C, Waller PJ, Hansen JW. The prevalence of anthelmintic resistance in nematode parasites of sheep in Southern Latin America: Paraguay. Vet Parasitol 1996; 62(3-4): 207-212. http:// dx.doi.org/10.1016/0304-4017(95)00907-8. PMid:8686166.

Maingi N, Bjørn H, Dangolla A. The relationship between faecal egg count reduction and the lethal dose $50 \%$ in the egg hatch assay and larval development assay. Vet Parasitol 1998; 77(2-3): 133-145. http://dx.doi. org/10.1016/S0304-4017(97)00222-7. PMid:9746283. 
Mena LAE, Arellano MEL, Gives PMG, Hernández EL, Prats VV, Ycuspinera GV. Primer informe en México sobre la presencia de resistencia a ivermectina en bovinos infectados naturalmente com nematodos gastrointestinales. Vet Mex 2008; 39(4): 423-428.

Moher D, Liberati A, Tetzlaff J, Altman DG. Preferred reporting items for systematic reviews and meta-analyses: the PRISMA statement. Int J Surg 2010; 8(5): 336-341. http://dx.doi.org/10.1016/j.ijsu.2010.02.007. PMid:20171303.

Neyeloff JL, Fuchs SC, Moreira LB. Meta-analyses and Forest plots using a Microsoft Excel spreadsheet: step-by-step guide focusing on descriptive data analysis. BMC Res Notes 2012; 5(1): 52. http://dx.doi. org/10.1186/1756-0500-5-52. PMid:22264277.

Rangel VB, Leite RC, Oliveira PR, Santos EJ Jr. Resistência de Cooperia spp. e Haemonchus spp. às avermectinas em bovinos de corte. Arq Bras Med VetZootec 2005; 57(2): 186-190. http://dx.doi.org/10.1590/S010209352005000200008 .

Ranjan S, Trudeau C, Prichard RK, von Kutzleben R, Carrier D. Efficacy of moxidectin against naturally acquired nematode infections in cattle. Vet Parasitol 1992; 41(3-4): 227-231. http://dx.doi.org/10.1016/03044017(92)90082-K. PMid:1502785.

Ravinet N, Chartier C, Bareille N, Lehebel A, Ponnau A, Brisseau $\mathrm{N}$, et al. Unexpected Decrease in Milk Production after Fenbendazole Treatment of Dairy Cows during Early Grazing Season. PLoS One 2016; 11(1): e0147835. http://dx.doi.org/10.1371/journal.pone.0147835. PMid:26808824.

Reinemeyer CR, Cleale RM. Dose confirmation studies of moxidectin $1 \%$ non-aqueous injectable and moxidectin $0.5 \%$ pour-on formulations against experimentally induced infections of larval and adult stage Oesophagostomum radiatum and Trichuris discolor in cattle. Vet Parasitol 2002; 108(1): 75-83. http://dx.doi.org/10.1016/S0304-4017(02)001802. PMid:12191901.

Rodríguez-Vivas RI, Castillo-Chab CG, Rosado-Aguilar JÁ, Ojeda-Chi MM. Evaluación de la eficacia y persistencia de la moxidectina (10\%) e ivermectina $(3,15 \%)$ contra infecciones naturales de nematodos gastrointestinales en bovinos del trópico mexicano. Arch Med Vet 2014; 46(1): 69-74. http://dx.doi.org/10.4067/S0301-732X2014000100010.
Sargeant JM, Rajic A, Read S, Ohlsson A. The process of systematic review and its application in agri-food public-health. Prev Vet Med 2006; 75(3-4): 141-151. http://dx.doi.org/10.1016/j.prevetmed.2006.03.002. PMid:16725217.

Sievers G, Alocilla A. Determinación de resistencia antihelmíntica frente a ivermectina de nematodos del bovino en dos predios del sur de Chile. Arch Med Vet 2007; 39(1): 67-69. http://dx.doi.org/10.4067/S0301732X2007000100010.

Sievers G, Fuentealba C. Comparación de la efectividad antihelmíntica de seis productos comerciales que contienen lactonas macrocíclicas frente a nematodos gastrointestinales del bovino. Arch Med Vet 2003; 35(1): 81-88. http://dx.doi.org/10.4067/S0301-732X2003000100008.

Stafford K, Coles GC. Nematode control practices and anthelmintic resistance in dairy calves in the south west of England. Vet Rec 1999; 144(24): 659-661. http://dx.doi.org/10.1136/vr.144.24.659. PMid:10404603.

Suarez VH, Cristel SL. Anthelmintic resistance in cattle nematode in the western Pampeana Region of Argentina. Vet Parasitol 2007; 144(1-2): 111 117. http://dx.doi.org/10.1016/j.vetpar.2006.09.016. PMid:17049746.

Sutherland IA, Leathwick DM. Anthelmintic resistance in nematode parasites of cattle: a global issue? Trends Parasitol 2011; 27(4): 176-181. http://dx.doi.org/10.1016/j.pt.2010.11.008. PMid:21168366.

Van Wyk JA, Malan FS. Resistance of field strains of Haemonchus contortus to ivermectin, closantel, rafoxanide and the benzimidazoles in South Africa. Vet Rec 1988; 123(9): 226-228. http://dx.doi.org/10.1136/ vr.123.9.226. PMid:3176284.

Vercruysse J, Dorny P, Claerebout E, Demeulenaere D, Smets K, Agneessens J. Evaluation of the persistent efficacy of doramectin and ivermectin injectable against Ostertagia ostertagi and Cooperia oncophora in cattle. Vet Parasitol 2000; 89(1-2): 63-69. http://dx.doi.org/10.1016/ S0304-4017(00)00193-X. PMid:10729646.

Yazwinski TA, Tucker CA, Wray E, Jones L, Reynolds J, Hornsby P, et al. Control trial and fecal egg count reduction test determinations of nematocidal efficacies of moxidectin and generic ivermectin in recently weaned, naturally infected calves. Vet Parasitol 2013; 195(1-2): 95-101. http://dx.doi.org/10.1016/j.vetpar.2012.12.061. PMid:23380250. 